Maurer School of Law: Indiana University

Digital Repository @ Maurer Law

\title{
Law and the "Other": Karl N. Llewellyn, Cultural Anthropology, and the Legacy of The Cheyenne Way
}

Ajay K. Mehrotra

Indiana University Maurer School of Law

Follow this and additional works at: https://www.repository.law.indiana.edu/facpub

Part of the Cultural Heritage Law Commons, and the Social and Cultural Anthropology Commons

\section{Recommended Citation}

Mehrotra, Ajay K., "Law and the "Other": Karl N. Llewellyn, Cultural Anthropology, and the Legacy of The Cheyenne Way" (2001). Articles by Maurer Faculty. 2530.

https://www.repository.law.indiana.edu/facpub/2530

This Article is brought to you for free and open access by the Faculty Scholarship at Digital Repository @ Maurer Law. It has been accepted for inclusion in Articles by Maurer Faculty by an authorized administrator of Digital Repository @ Maurer Law. For more information, please contact rvaughan@indiana.edu. 


\section{Law and the "Other": Karl N. Llewellyn, Cultural Anthropology, and the Legacy of The Cheyenne Way}

Ajay K. Mehrotra

Karl N. Llewellyn and E. Adamson Hoebel. The Cheyenne Way: Conflict and Case Law in Primitive Jurisprudence. Norman: University of Oklahoma Press, 1941. Pp. 360.

In the summer of 1935, a well-known legal academic and a young anthropologist ventured together to the Tongue River Reservation in Lame Deer, Montana, to study the legal culture of the Cheyenne. Through the recollections of the elder members of the tribe, the two scholars came to understand how the Cheyenne resolved their social disputes and how they "cleaned up the messes" of homicide, theft, adultery, and the like. The lawyer and anthropologist, having analyzed over 50 "trouble-cases," were astonished by the "juristic beauty" and "legal genius" of Cheyenne dispute resolution. Studying the legal processes of the non-Western "other" exemplified for them the role of law in channeling human behavior and maintaining social cohesion. The Cheyenne had-or so it appeared to the two observers-the unique, problem-solving ability to reconcile general notions of law with the particular dictates of individual justice. The legal academic in charge of the study was Karl N. Llewellyn, the Betts professor of jurisprudence at Columbia University Law School; his anthropologist assistant was E. Adamson Hoebel, a junior faculty member at New York University and a former Llewellyn student. The culmination of their work, which included

Ajay K. Mehrotra is a doctoral candidate in U.S. history at the University of Chicago. For their assistance on earlier versions of this essay, he'd like to thank Kathleen Conzen, Daniel Ernst, Allen Kamp, Robert McLaughlin, William Novak, Richard Ross, David Schwartz, Michael Silverstein, George Stocking, and Mark Tushnet. 
another summer in the field and several years of writing and editing, became The Cheyenne Way.

Upon publication, The Cheyenne Way gained nearly instant recognition among many anthropologists and a small number of legal scholars as groundbreaking work in the field of legal anthropology (Lowie 1942; Malinowski 1942; Redfield 1942; Pound 1943). Generally, the discipline of anthropology embraced the teachings of the book. The methodology of focusing on dispute resolution, or what the authors' called "trouble-cases," was seen by many social and cultural anthropologists of the time as a new and productive way to understand "tribal culture." The legal academy, however, was slow to acknowledge the importance of tribal ethnography for the study of law. Most legal scholars, even progressive-minded ones, ${ }^{\prime}$ believed that because "primitive" societies bore little resemblance to the modern world, anthropology had little to offer the study of law.

Nearly 60 years after its initial publication, the dichotomous legacy of The Cheyenne Way remains with us. Anthropologists continue to mark the text as the "beginning of modern studies in the anthropology of law" (Gulliver [1969]1997, 11), and as one of the "great classics of legal anthropology" (Rouland 1994, 38). By contrast, legal scholars have paid scant attention to how the Cheyenne study has informed legal discourse. ${ }^{2}$ As Llewellyn's biographer has observed (Twining 1973), American legal scholars in particular have neglected Llewellyn's innovative anthropological and sociological approach to the study of law (Twining 1993). ${ }^{3}$

The disjointed effect of The Cheyenne Way and the general fissure between law and ethnography are of major importance in light of contemporary concerns about the relationship between law and society. At a time when one set of legal scholars is embracing a so-called new school of law and social norms (Sunstein 1996; Lessig 1998), and others are questioning the future vitality of the law and society movement (Simon 1999), it may be helpful to take a closer look back at one of the early efforts to bridge the gap between the legal and social spheres. Indeed, analyzing the historical context in which The Cheyenne Way was written may help us understand the general importance and continued need for research conducted at the

1. According to Laura Kalman, even some of Llewellyn's progressive-minded colleagues, such as Felix Cohen and Jerome Frank, admired anthropology but nevertheless marginalized it because of its perceived limited value for understanding the workings of a complex, modern society. "When Llewellyn published The Cheyenne Way . . Frank announced that Llewellyn would have better spent his time studying the law-ways of Tammany Hall braves than the Cheyenne Indians" (Kalman 1986, 18).

2. Notable exceptions include the literature discussed below, and several recent law review articles that have explored the connections between Llewellyn's interests in anthropology and commercial law (Papke 1999a; Kamp 1995, 1998). Outside the field of commercial law, however, few legal scholars have even bothered to examine The Cheyenne Way.

3. Twining credits British, German, and Australian writers for being more receptive to Llewellyn's social scientific methods. See Twining 1993, 123 n.11. 
intersection of law and society. It may also help us appreciate the specific saliency of ethnography for the study of legal and social norms.

This essay attempts to contextualize the original insights and methodological limits of The Cheyenne Way. In doing so, it deals with the larger question of authorial motivation and intent. This essay, in other words, seeks to answer a set of historical questions: Why was Llewellyn, a professor of jurisprudence and commercial law, interested in cultural anthropology and the study of "primitive law"? Did his jurisprudence or sociology of law require him to explore the elementary functions of law in less complex societies? Did his interest in ethnography inform his jurisprudence? Was there something distinctive about the anthropological approach, something that the other emerging social sciences could not capture about the essence or particularities of law? Or can one perhaps glibly dismiss Llewellyn's fascination with the Cheyenne as merely the passing fancy of an eclectic, intellectual dilettante?

Scholars addressing these questions have tended, for the most part, to focus on how Llewellyn's affinity for cultural anthropology corresponded with his overall legal theory. Most researchers have concluded that Llewellyn's ethnographic interest in "primitive law" was part and parcel of his greater legal realist jurisprudence--a jurisprudence that sought to throw off the formalistic, conceptual view of legal reasoning in favor of a more empirical, sociological approach to law. ${ }^{4}$ Viewing the Cheyenne project as a "laboratory for realism" (Hull 1997, 286), and as the wedge with which "legal realism entered the anthropology of law" (Vincent 1990, 250), many scholars have argued that cultural anthropology was just one of the many intellectual influences affecting Llewellyn's diverse and capacious mind. ${ }^{5}$ The legal historian N. E. H. Hull, for example, has argued that Llewellyn, like Roscoe Pound, was a synthesizer or "bricoleur, who put together bits and pieces of existing theories to innovate a new American approach to legal thought" (Hull 1997, 5). ${ }^{6}$

While there is little doubt that The Cheyenne Way was, as William Twining has documented, both an outgrowth of Llewellyn's early legal realist empiricism and an inspiration for his later realist writings (Twining

4. Whether legal realism was a coherent movement or school of thought remains a contested issue among historians. For more on legal realism, see Purcell 1973; Twining 1973; Kalman 1986; Horwitz 1992; Duxbury 1995; Schlegel 1995; Hull 1997.

5. Because of Llewellyn's prominent role in American jurisprudence and commercial law, a virtual cottage industry of scholarship on Llewellyn has emerged, with researchers examining everything from the German roots of his thought (Whitman 1987; Ansaldi 1992) to his place among Progressive Era (Horwitz 1992) and New Deal theorists (Kamp 1995) to his personal bouts with alcoholism and depression (Connolly, Pschirrer, and Whitman 1998).

6. Not all scholars, however, have looked upon Llewellyn's use of cultural anthropology with such approval. Alan Hunt has argued that Llewellyn's anthropological view suffers from "extreme functionalism" (Hunt 1978, 50), while Scott Landers has disputed whether Llewellyn was successful in displacing rule-based jurisprudence with a behavioral approach to law (Landers 1996). 
1973, 169), Llewellyn's collaboration with Hoebel was also much more. The Cheyenne Way was one of the pioneering collaborative efforts to combine the studies of law and society. The book was, and is, part of the genealogy of interdisciplinary work between law and anthropology-a genealogy that contains much of the promise and perils that remain a part of interdisciplinary work today.

This essay seeks to uncover this genealogy in an effort to revitalize the current connections between law and the social sciences. By highlighting the broader context of The Cheyenne Way, this essay first analyzes the romantic, neo-evolutionary tone of Llewellyn and Hoebel's study. Legal historians have shown how Llewellyn used the Cheyenne study and its "trouble-case" methodology to dissolve the binary distinction in legal theory between process and substance-how Llewellyn, in other words, demonstrated that the "ought" of substantive rules could not be separated from the "is" of legal and social processes (Twining 1973; Hull 1997). This historical literature, however, has neglected to emphasize how Llewellyn's nostalgic analysis of Cheyenne "law-ways" implicitly perpetuated a much larger dichotomy between modern and nonmodern societies, or what Llewellyn and Hoebel called the difference between "complex" and "primitive" cultures.

This essay also examines the contributions and confines of Llewellyn's legal pluralism. Some scholars have hailed The Cheyenne Way as a bold and early effort in explaining the coexistence of diverse and often conflicting legal norms and processes within and between social groups (Vincent 1990, 251; Rouland 1994, 47). But little has been written about how Llewellyn and Hoebel overlooked the historical transformations of their ethnographic subjects and the socioeconomic context in which they lived. Llewellyn and Hoebel depicted the internally dynamic nature of Cheyenne "law-ways" as a legal culture that was externally insulated from the larger context of American political power and capitalistic economic development. Despite Llewellyn's claims to the contrary, the Cheyenne of the Northern Plains-or for that matter any other Native American group at the time-were not an untouched quasi-laboratory in which Llewellyn could test out his legal realist tenets. Rather, the Cheyenne existed amid a multitude of cross-cultural influences, not least of which was the web of American expansionism that included transcontinental movements of people and capital.

Part 1 of this essay provides a brief biographical sketch of Llewellyn, summarizing his formal education, his scholarship, and his influence on legal and social scientific knowledge. Part 2 discusses the context in which The Cheyenne Way was written. Using the published and unpublished works of Llewellyn, his research notes and grant proposals, and his private 
correspondences, ${ }^{7}$ this section explores how Llewellyn may have dissolved one set of binaries only to reify another. Finally, part 3 investigates the innovations and limitations of Llewellyn's legal pluralism by taking a closer look at the actual ethnographic results of The Cheyenne Way.

\section{KARL NICKERSON LLEWELLYN: "HALF-LAWYER, HALF-SOCIOLOGIST"}

Throughout his life, Llewellyn fancied himself an acute observer of the cultural practices and social relations of various communities. From his childhood and adolescent years in New York City and Mecklenburg, Germany ${ }^{8}$ to his formal education at Yale, to his years as a senior scholar, Llewellyn was fascinated by an eclectic set of interests. This diversity of interests was held together less by a systematic mind than a capacious one. Reared and educated in a cosmopolitan environment, Llewellyn was exposed at an early age to a large variety of cultures and communities. And it appears that, from the beginning, Llewellyn absorbed these multicultural experiences as part of his informal sociological training. Early in his career as a law professor, Llewellyn boldly claimed that he had always been a student of human society. In an early manuscript, Llewellyn went so far as to label himself a "half-lawyer, half-sociologist," who for decades had used "the methods of the cultural anthropologist on first-hand study of groups alien to his personal background." These groups included "boys-groups in summer camp; Germans in Germany; German-Americans in New York; Jews in New York; French in France; The National City Bank, 1920-22," and just about any other group Llewellyn had come in contact with over his life (Llewellyn 1935a).

Yet despite his claims at being a self-educated social scientist, Llewellyn likely first became familiar with the rigorous, ethnographic methods of anthropology and sociology during his college years. Llewellyn received his formal education at Yale University, where he obtained his undergraduate and law degrees. It was at Yale where Llewellyn learned about the sociological theories of William Graham Sumner through the teachings of Albert G. Keller, one of Sumner's disciples teaching at Yale during Llewellyn's college

7. The majority of the archival research material for this paper is from the Karl Llewellyn Papers at the University of Chicago Law School. For an overview of the Llewellyn papers, see generally Ellinwood and Twining 1970; Lewis 1994.

8. At the age of 16, Llewellyn's parents sent young Karl to Europe to attend the Realgymnasium at Schwerin in Mecklenburg, Germany. During his three years in Germany, Llewellyn became fluent in German and developed an affinity for Teutonic culture. This early attraction to Germany led Llewellyn to return to fight in the German army during WWI, and to return often, later in life, as a visiting lecturer in law at the University of Leipzig (Twining, 1973, 87-89). For more on the German influence on Llewellyn, see Whitman 1987; Ansaldi 1992; Drobnig 1994; Riesenfeld 1994. 
years. As one of the pioneer's of American sociology, Sumner is often remembered today as an early proponent of social Darwinism. Although those who have studied Llewellyn have suggested that the writings of Sumner acted mainly as a counterbalance to Llewellyn's radicalism (Twining 1973, 93; Hull 1997, 137), it is also possible that Sumner's evolutionary determinism profoundly affected the young college student. Llewellyn himself later credited Keller and Sumner as direct influences on his intellectual formation, claiming that reading Sumner in particular had been one of the most exciting experiences of his undergraduate days (Twining 1973, 92, 414 n.25).

Llewellyn's enthusiasm in studying the social and cultural aspects of society continued into his legal education, where he received a heavy dose of the holistic integration of law and society. With WWI raging, Llewellyn's law school years were marked by what he perceived to be a paucity of quality peers. This drawback allowed Llewellyn to become unusually close to several of his instructors, including a cadre of early legal realists-such as Arthur Corbin, Wesley Hohfeld, and Walter Wheeler Cook-who were all interested in the empirical mechanics of law. Under the tutelage of these instructors, especially Corbin whom Llewellyn became extremely close to, ${ }^{9}$ Llewellyn adopted much of the antiformalist, rule skepticism that would dominate his scholarship and legal theory. The "new approach" emerging at Yale Law School at the time questioned the reigning conceptualist orthodoxy. Scholars like Hohfeld were highlighting the ability of lawyers to manipulate canonical verbal formulations to demonstrate the conflicting meanings and interpretations of what were thought to be straightforward rules (Kalman 1986). Llewellyn absorbed this antiformalist thinking in constructing his sociologically based "juristic method," or what he often referred to as his "law-jobs theory." 10 Two decades after law school, in an unpublished appendix to The Cheyenne Way, Llewellyn credited his college and law professors for guiding him in his intellectual odyssey through law and culture. "I hit the law jobs first under the star of Keller, and Sumner (in that order)," wrote Llewellyn, "and then of Hohfeld (the atomizer), Cook (the logician), Corbin (the combiner of Hohfeld and Cook with Sumner-like thinking)" (Llewellyn 1940?).

After completing both his LL.B. and J.D. at Yale Law School, Llewellyn taught part-time for a year at Yale, and then entered private practice. That first year of part-time teaching foreshadowed much of Llewellyn's future research interests, as he was invited then to teach classes on commercial law and jurisprudence, the two subjects for which he is best remembered

9. In nearly all the correspondences between Corbin and Llewellyn that are contained in the Karl Llewellyn Papers, Llewellyn has addressed Corbin as Dad, and in a few responses Corbin has concluded with "Dad" (Corbin 1960; see also Corbin 1962).

10. For more on the particulars of Llewellyn's "juristic method" and "law-jobs theory," see Twining 1993. 
today. But Llewellyn's initial teaching experience is important for yet another reason, for it was this early engagement with legal theory absent any practical knowledge that verified for Llewellyn the need to understand the everyday methods and practices of legal systems. "I hadn't been in [teaching] for more than a year and a half," recalled Llewellyn a few years after his initial teaching experience, "when it became clear to me that the things I was finding in the cases had very little indeed to do with what was going on in practice. ... It became clear to me that there was no hope for me to make any headway at all in the investigations I was interested in, unless I found out what was going on de facto in practice" (Twining 1973, 101). To satisfy his need for practical experience-this desire to reconcile theory with practice-Llewellyn moved to New York City in 1920 and joined the legal department of the National City Bank, which at the time was transferring its legal department to the Wall Street law firm of Sherman and Sterling (Corbin 1962).

After two years of private practice, specializing in banking law, Llewellyn returned to the legal academy. He began his long and distinguished academic career teaching briefly first at Yale Law School, where in addition to his research interest in commercial law, Llewellyn offered a class in the Department of Anthropology and Sociology entitled "Law in Society" (Papke 1999b; Corbin 1962). For personal reasons, Llewellyn left Yale in 1924 after only two years to join the faculty at Columbia Law School, where he spent the majority of his life as a law professor. ${ }^{11}$ Llewellyn eventually left Columbia for the University of Chicago decades later, but it was in Morningside Heights that Llewellyn made his mark in the academic community.

During these years at Columbia, Llewellyn began his prolific scholarship, writing first in the field of commercial law and then jurisprudence. His Cases and Materials in the Law of Sales (1930) and The Bramble Bush ([1930]1951), and his public discourse with Roscoe Pound-then the dean of the Harvard Law School-over the meaning of legal realism (Hull 1997, 173-222), established Llewellyn as one of the preeminent members of a new generation of legal scholars. This stature was enhanced further in the ensuing decade of the 1940s when the American Law Institute and the Conference on Commissioners on Uniform State Laws appointed Llewellyn chief reporter in charge of drafting and promoting the Uniform Commercial Code (Papke 1999a, b). While at Columbia, Llewellyn cultivated his interdisciplinary skills by interacting with a vast number of other social scientists

11. The personal reason that brought Llewellyn to Columbia in 1924 was his marriage to his first wife Elizabeth Sanford, who at the time was a graduate student in Columbia's economics department. Llewellyn was excited by the move, especiaily with the overall preeminence of Columbia's social science departments and law faculty. In a letter to Llewellyn, fellow realist Joseph Bingham called Columbia at the time, "the best legal laboratory in America" (Bingham 1930). 
at the university, including Franz Boas and Ruth Benedict of the anthropology department and John Dewey in philosophy. ${ }^{12}$ Columbia was also the place where Llewellyn met a young anthropology graduate student by the name of E. Adamson Hoebel, and the two of them, through the support of the university, were able to undertake the Cheyenne project.

After nearly three decades at Columbia, Llewellyn resigned in 1951 and took his social scientific analysis of law with him to the University of Chicago Law School, ${ }^{13}$ where he remained until his death in 1962. Two years prior, Llewellyn had published his magnum opus, The Common Law Tradition: Deciding Appeals (1960). In it, he echoed the antiformalist rule skepticism that had been at the heart of his legal theory and scholarship throughout his career. Llewellyn himself viewed this final research project as "the anthropological jurisprudence of American appellate courts" (Hoebel 1964), explicitly calling it his "study of law-ways and primitive law among the higher United States legal shamans."14 With a legal career that spanned over four decades, Llewellyn was remembered at his death as "one of the nation's distinguished legal philosophers," and his long-time interlocutor, Roscoe Pound, hailed Llewellyn's life-long scholarship as "the most basic and thoroughly thought-out sociological theory of law which has yet appeared" (New York Times 1962).

\section{FROM ONE BINARY TO ANOTHER: THE HISTORICAL CONTEXT OF THE CHEYENNE WAY}

Llewellyn's sociological theory of law, as Pound referred to it, was rooted at bottom in an effort to move beyond the formalist view of law that was dominant during the early twentieth century. Both the legal and anthropological literature at the time, Llewellyn argued, was obsessed with what he and Hoebel called "the ideological" approach to law-the study of formal, substantive rules, or ideal norms, of a society or culture ( $p$. 20). Substantive law, according to the ideological approach, was seen as

12. Llewellyn and Hoebel often referred in their later letters to Boas as "Papa Franz." And when a bust to commemorate Boas was commissioned by Columbia University, Llewellyn was responsible for its placement (Llewellyn 1948). Twining suggests that Llewellyn often attended Dewey's seminars on legal philosophy, and that "Llewellyn's private ambition ... was to perform the role of Dewey in jurisprudence, trying to do for law what the great man had done for other subjects" (Twining 1973, 422-23 n.13).

13. It is highly ironic that Llewellyn and his anthropological and sociological approaches to law are largely unrecognized by the "New Chicago School" of social norms. Critics of this new school have argued that the inquiry of social norms requires "a kind of cultural investigation that seems foreign to the new Chicago school, and that would surely be better conducted through engagement with sociological and anthropological studies and theory" (Tushnet 1998, 584).

14. Hoebel claimed that Llewellyn had inscribed the latter quote in Hoebel's copy of The Common Law Tradition (Hoebel 1964). 
something unique and separate from the process that defined it. For Llewellyn the distinction between substance and process was a false choice. Throughout his scholarship he argued for a "working whole view" as an alternative to the substance/process binary (Twining 1993, 126). By applying social scientific methods to the analysis of dispute resolution, Llewellyn believed, one could see that process and substance were two sides of the same coin. The Cheyenne Way was, thus, an opportunity to demonstrate how an ethnographic investigation of law could prove that merely relying on a formal rule-centered analysis of society was incomplete at best.

But the research among Native Americans proved to be much more for Llewellyn. The Cheyenne research project was not an isolated undertaking; it was rather part of a much larger and more ambitious research agenda established by Llewellyn to form a comparative understanding of Native American legal institutions. This larger project led Llewellyn to an implicit, romantic, and neo-evolutionary view of Cheyenne law and culture-a view that seemed at odds with Llewellyn's high praise for the "juristic beauty" of Cheyenne "law-ways."

\section{A. "The Crucible of Conflict": The Insights of Studying Dispute Resolution Processes}

Like his legal realist colleagues, Llewellyn eschewed the traditional legal emphasis on rules and doctrines in favor of a more empirical examination of how the law worked. And how it worked in settling disputes was of paramount importance to Llewellyn. "This doing of something about disputes, this doing it reasonably, is the business of law," Llewellyn wrote in one of his most famous early lectures. "And the people who have the doing in charge, whether they be judges or sheriffs or clerks or jailers or lawyers, are officials of the law. What these officials do about disputes is, to my mind, the law itself" (Llewellyn [1930]1951, 3, emphasis in original). ${ }^{15}$

This identification of law with the processes of dispute resolution is an example of what Grant Gilmore has described as Llewellyn's "consistent, almost unconscious preference for the particular over the general" (Gilmore 1962, 813). Indeed, Llewellyn had little patience with any highbrow legal theory that neglected the everyday specifics of the law. Throughout his academic career, Llewellyn disdained highbrow philosophy as an "esoteric tradition" far removed from the realities of everyday life. Even in his jurisprudence classes, he went to great lengths to relate his lessons on the theory of law to both the craftsmanship of being a lawyer and the daily lives

15. Llewellyn's definition of law was remarkably similar to Oliver Wendell Holmes's own axiom about law being the prediction of what the courts will do in fact (see Holmes 1897). Like other legal realists, Llewellyn often recognized Holmes and his writings as the foundation of legal realism. 
of his students. Llewellyn, ever the democrat, preferred "jurisprudence for the hundred thousand (for the bar and for the intelligent layman)," rather than the specialized, academic "jurisprudence of the hundred" (Twining $1973,173)$. In describing his jurisprudence course, Llewellyn once wrote, "My general jurisprudence is a general over-all course on common sense, techniques, and the basic ideals of law, with very little relation to the hogwash current in the field" (Llewellyn 1951).

To understand how everyday legal practices operated on the ground, Llewellyn turned to the social sciences. The behavioral and empirical aspects of the social sciences could help legal theory see beyond the myopia of the doctrinal approach. Understanding how law affected everyday social relations, Llewellyn believed, could show how substantive rules were inextricably tied to ordinary social processes. Indeed, the social sciences, particularly the ethnographic methods of anthropology and sociology, had much to offer the study of law, Llewellyn argued. First, a social scientific approach to law could, through comparative analysis, broaden one's understanding of law in society. Llewellyn and his progressive-minded colleagues had been urging legal scholars secluded in libraries to leave the cloistered world of "armchair scholarship" for authentic empirical fieldwork. ${ }^{16}$ The social sciences provided the methodologies and models to guide this empirical research and to develop the legal academy's understanding of how law operated within and between cultures. The comparative aspects of cultural anthropology, Llewellyn believed, could be used to broaden the horizons and ignite the imagination of legal thinkers, without causing them to float into the esoteric world of legal philosophy. Upon hearing the news that a visiting legal and anthropological scholar had arrived from South Africa, Llewellyn was ebullient: The "picture of having the outlook not only of the students, but also of the faculty enlarged by the understanding of simpler legal systems and 'kicked' into imagination by the problems of dealing both with simpler systems and with rising cultures is one which makes me rejoice," wrote Llewellyn. "You know that I would do no rejoicing if I thought this meant 'cloud thinking' without hands and feet" (Llewellyn 1961).

A social scientific approach to law, Llewellyn argued, could also have practical benefits. Unlike the doctrinal or ideological approach, a behavioral or empirical analysis of law-one informed by the teachings of the social sciences-could enable law to keep pace with a changing social reality, making it more effective as a flexible scientific instrument. "I study social science," Llewellyn wrote early in his career as a law professor, "not for any love of things that are, or belief in their rightness, but because attempted change seems useless until one finds the laws of change-what can

16. Boas had been making similar calls to his anthropological colleagues to give up isolated library projects for ethnographic fieldwork (Stocking 1974). 
be changed, and how, and with what result" (quoted in Twining 1973, 93). ${ }^{17}$ Finding the levers of change was thus, for Llewellyn, the first step in undertaking any kind of legal reform. Since the law itself was a sociocultural phenomenon for Llewellyn, as Soia Mentschikoff, Llewellyn's colleague and third wife often noted, Llewellyn had to understand how law operated within this social and cultural context, before he could expect to reform the law. "To Llewellyn, law in any society was inextricably bound up with, influenced by, and influencing that society's culture," wrote Mentschikoff in discussing the significance of The Cheyenne Way. "[Llewellyn] studied other cultures to gain insight into things legal and he used that insight to argue for improvement in our legal culture, particularly in the adjudicatory mechanisms employed in dispute setrlement" (Mentschikoff and Stotzky 1986).

Others, of course, built on this foundation of sociolegal analysis, especially within the varying disciplines of the social sciences. But in the 1930s and 1940s Llewellyn sincerely believed he was breaking new ground by bridging the study of law with the social sciences. By using the ethnographic methods of anthropology, Llewellyn believed he was exposing the vulnerabilities of formalist legal thought. He was demonstrating with his sociological analysis of legal culture that law needed to be studied at the level of detailed particulars, where social relations were guided by the practices and processes, or what he called the "law-ways," of groups and subgroups. ${ }^{18}$ The anthropological study of Cheyenne "law-ways," thus, became, for Llewellyn, an opportunity to illustrate how social processes could not be divorced from formal rules.

In an unpublished manuscript that preceded The Cheyenne Way, Llewellyn discussed his admiration and disappointment with anthropology's then-current approaches to law. Applauding anthropology's focus on the particular rather than the universal, he was impressed by the discipline's recent attempt to uncouple law from custom. Early anthropologists such as Sir Henry Maine had done much to conflate the two concepts of law and custom, Llewellyn argued. But Llewellyn for one was thankful for "the increasing care and sense with which efforts are being made to discriminate legal practices and norms from the rest of the practices and norms - a grateful sign of freedom from the older choking identification of 'law' and 'custom." Custom was also being broken down "in terms of degrees of

17. A similar notion of understanding change before undertaking reform was shared by many anthropologists, especially Sol Tax, who was a colleague of Llewellyn's in the anthropology department at the University of Chicago (Stocking 1999, 2000).

18. It is important to note Llewellyn's attention to language. By using terms such as "law-ways" and "law-stuff" he meant to include within his view of law the numerous social practices and processes within a society that related to the law. Llewellyn was not, however, consistent with his awareness of language, as he freely used terms such as "primitive" and "modern" to divide foreign "otherness" from what he was familiar with. Both law and anthropology have since become more aware of the power of language. See Conley and O'Barr 1998; Comaroff and Comaroff 1992. 
uniformity of behavior, with careful allowance for alternative patterns." This too allowed one to focus on the detailed ways in which cultures differed. Llewellyn was doubly impressed by anthropology's scientific attempt to situate law within culture, something that comparative lawyers were trying to do themselves. "The second feature [of anthropology] impressing the outsider is the care with which the now differentiated legal practices are being set in the oyster of the culture which has secreted them," wrote Llewellyn. "Here is the virtue the historical jurisprudents were groping for, but set up this time in such fashion that interpretative sense can replace mysticism" (Llewellyn 1935a, 1-3, emphasis in original).

Anthropology's approach to law also had its drawbacks, however. Llewellyn claimed that anthropology had not only ignored the importance of what is absent in a culture, ${ }^{19}$ but more important, neglected to study the subcultures of American society itself. Unaware of how anthropologists were in fact studying American culture at the time, Llewellyn's comment was probably intended to be less a criticism of anthropology than support for his own ethnographic studies. His point was to emphasize the existence of subcultures within the greater, undifferentiated whole. He held "firmly to the view that most instructive analogues to primitive cultures can be found among the infinite sub-groupings of a modern society, once they are viewed as divergent semi-unities rather than as undiscriminated fungible bricks in 'a' whole" (Llewellyn 1935a, 3). Differentiating subcultures from what appeared to be a homogenous society was important for Llewellyn because it was at this subcultural level where one could see how social processes were fused with substantive rules. The formal and ideological approach to law, Llewellyn argued, did not make this added effort to parse through the disparities of social organization, and for this reason, the ideological approach was unable to grasp how rules received their meanings from the processes that contained them.

In contrast to the ideological approach, anthropological studies of law in the early decades of the twentieth century focused on patterns of behavior, describing the richness of social practices. Llewellyn preferred this descriptive path, but he along with Hoebel yearned for even greater attention to detail. An example of this descriptive approach in anthropology was the work of Bronislaw Malinowski, one of the founders of modern British social anthropology. Malinowski's direct ethnographic study of the Trobriand Islanders (Malinowski 1926) was one of the clear influences on the formation of The Cheyenne Way. Malinowski's work directly proceeded The Cheyenne Way as the classic text of legal anthropology, and in this sense Malinowski's

19. Recognizing the importance of the act/omission distinction was critical for Llewellyn, who wrote, "In the negation (or affirmance) of other possibilities suggested by the situation as possible, lies the difference between the conclusive job that really tests an hypothesis and the inconclusive one which-as to a given culture-merely offers one" (Llewellyn 1935a, 3). 
empirical work became both an inspiration and foundation for Llewellyn and Hoebel. Combating the ideological approach to tribal law, which concentrated on the articulated rules of a society, Malinowski documented the nonarticulated forms of coercion and cohesion that existed in tribal cultures. By focusing on the reciprocal obligations attached to tribal customs, Malinowski demonstrated that law could exist even in those cultures where no set, precise rules are stated.

Llewellyn and Hoebel admired Malinowski's revolutionary work, but they seemed agitated by its generality and abstraction (Twining 1973, 160). Malinowski "shows no sign of there being any adjudicating machinery, no sign even of open 'law' enforcement," Llewellyn wrote in an unpublished appendix to The Cheyenne Way. "It is regrettable that we have from Malinowski no clear and detailed statement as to whether and how far the political chief exercises legal functions" (Llewellyn 1940?). "What officials do about disputes" continued to resonate as the essence of law for Llewellyn. Using their emphasis on studying conflict, Llewellyn and Hoebel had hoped to build on the foundation established by Malinowski. Whereas Malinowski's empirical evidence was based on accounts of tribal customs, Llewellyn and Hoebel focused their fieldwork on "trouble-cases," believing that a casebased method of research could add an element of rigor and rationale to the study of "primitive" law.

The authors of The Cheyenne Way presented their "trouble-case" method as a third way in contrast to the descriptive and ideological models. But this third way was not meant to supplant either the rule-based or descriptive models of legal culture, as one recent critic has intimated (Landers 1996, 98). Rather, Llewellyn and Hoebel explicitly stated in The Cheyenne Way that "the three approaches are related," that "they flow into each other." Though the authors believed that their focus on dispute resolution might provide "the safest main road into the discovery of law," they were well aware that dispute resolution could not exist in a vacuum separate from the norms and patterns of social behavior. "[I]t is the case of hitch or trouble that dramatizes a 'norm' or a conflict of 'norms' which may have been latent. It forces conscious attention; it forces the defining of issues," Llewellyn and Hoebel wrote. "It is one more experiment toward new and clearer or more rigorous patterning both of behavior and of recognized and recognizable 'norm' into that peculiarly legal something one may call a 'recognized imperative"" (pp. 21, 29, 21).

The trouble-case method was, thus, meant to be part of a holistic analysis of culture. Llewellyn and Hoebel did not intend to replace the onedimensional methods of the ideological and descriptive models with another equally provincial analysis; they sought, instead, to combine the prevailing paradigms with an emphasis on dispute resolution. When one reviewer of The Cheyenne Way criticized the authors for relying too heavily on the cases 
of trouble, Llewellyn responded with characteristic zeal: "Let me note that there was no suggestion in our book that the use of the trouble-case is an adequate exclusive method of study." Rather, Llewellyn believed that analyzing disputes was critical for both the study of primitive and modern law because it was "an indispensable primary technique, uniquely illuminating when there are trouble-cases to be had. But in primitive law, as in modern, it yields full results only in conjunction with study of the structures of ideals and norms, and the structures of practice, the group crafts and craftsmen, and the going institutions" (Llewellyn 1942, emphasis in original).

Though Llewellyn and Hoebel acknowledged their debts to Malinowski, their empirical, case-based, process-centered methods remained tied to the Boas school of cultural anthropology. In a letter to Boas, written during the fieldwork for The Cheyenne Way, Llewellyn commented on how the focus on processes and procedures did much more than supplement the existing literature on Cheyenne culture. Llewellyn acknowledged that the American ethnographer George B. Grinnell had previously examined the Cheyenne (Grinnell 1915, 1923), but even his work would have to be revised with Llewellyn's and Hoebel's research findings: "It is amazing to see how even the able work of Grinnell, which stretched over 25 years, takes on a totally different light," wrote Llewellyn, "when inquiry is made directly and consciously into legal procedures and processes" (Llewellyn 1935c). Years after The Cheyenne Way, the discipline of anthropology continued to recognize the importance of Llewellyn's and Hoebel's empirical methods, as scholars built on the foundation of a case-based, process-centered ethnography (Gluckman 1955; Nader 1965; Gulliver [1969]1997; Comaroff and Roberts 1981; Merry 2000).

Llewellyn and Hoebel claimed, moreover, that this case-based, processcentered ethnography had the potential to illuminate much more than a society's legal culture. How a group resolved its disputes, they argued, could also shed light on all other crucial aspects of a culture. Conflict, as a category of analysis, was asserted as being the lens with which one could come to understand an entire culture. "[I]f there be a portion of a society's life in which tensions of the culture come to expression," wrote Llewellyn and Hoebel, "in which the play of variant urges can be felt and seen, in which emergent power-patterns, ancient security-drives, religion, politics, personality, and cross-purposed views of justice tangle in the open, that portion of the life will concentrate in the case of trouble or disturbance. Not only the making of new law and the effect of old, but the hold and thrust of all other vital aspects of the culture, shine clear in the crucible of conflict" (p. 29).

With its success in supplementing the doctrinal and descriptive analyses of law with a more empirically based investigation of conflict, The Cheyenne Way stands as a testament to the potential benefits of interdisciplinary work. The book's emphasis on social processes and what is actually done 
about disputes demonstrated that an isolated approach to the "ought" of a society's rules is incomplete without an understanding of the facts or the "is" of a society's social relations. The "is" and the "ought," like substance and process, the authors argued, are bound together. This was one of the main messages of the collaborative work between Llewellyn and Hoebel-a message that, as Twining has noted, resonated more with anthropologists studying law than with lawyer's examining culture (Twining 1973, 164).

Yet while The Cheyenne Way may have advanced the social scientific understanding of law, it also continued to reproduce a theoretical distinction between primitive and modern societies. Llewellyn and Hoebel claimed to be getting at the general through the particular, but when one examines the greater historical context in which The Cheyenne Way was written, it appears that their view was tinged with a romantic, neo-evolutionary perspective on the development of legal cultures and institutions.

\section{B. Perpetuating the Primitive/Modern Binary: The Origins of "Indian Law Project \#81"}

Despite its contributions to interdisciplinary sociolegal research, The Cheyenne Way is also highly inconsistent. Scholars who have praised the book throughout the years for the innovative aspects of the trouble-case methodology have also been quick to point out that the use of oral histories to salvage evidence of social processes is hardly the paragon of empirical scientific studies (Malinowski 1942; Twining 1973; Vincent 1990; Landers 1996; Moore 1999). The Cheyenne Way is also an example of a much greater, but generally unnoticed, limitation in Llewellyn's anthropological approach - a limitation that becomes all the more evident when one examines the broader historical context of the Cheyenne research project and the legacy of Llewellyn's teachings.

Although Llewellyn and Hoebel were inspired by first-hand ethnographic fieldwork, such as was done by Malinowski in the Trobriand Islands, their own collection of data was quite peculiar. Rather than observe for themselves how the Cheyenne resolved their disputes during times of trouble, Llewellyn and Hoebel relied on oral histories gathered during their fieldwork in the 1930s to reconstruct how the Cheyenne had resolved their individual disputes during the period from 1820 to 1880 . Thus, ultimately, the Cheyenne culture that Llewellyn and Hoebel set out to examine no longer existed. The legal culture they praised was simply a remnant recreated by a fragmentary assemblage of historical evidence. Nevertheless, the authors were confident that through careful corroboration they could substantiate much of what their informants told them. They also believed that even if some of their evidence was based on myths and fictions, they could still get at the heart of how Cheyenne disputes were settled. Indeed, 
Llewellyn, referring to the works of James Frazer and Thurman Arnold (Frazer 1923; Arnold 1937), intimated that nearly all cultures are fraught with some level of myth making that, when understood with care, could get at the concepts, values and attitudes that define a group (p. 67). Much has already been written about how this form of data collection belied the theory of investigation that the authors proffered (Twining 1973; Vincent 1990). Suffice it to say that Llewellyn and Hoebel were aware of these drawbacks, but they still sincerely believed that their approach was an efficient method to determine how Cheyenne disputes were handled.

What is more troubling about the content of The Cheyenne Way, however, is the implicit neo-evolutionary view of culture that undergirded Llewellyn's and Hoebel's overly romantic evaluation of Cheyenne culture. Throughout the monograph, Llewellyn and Hoebel heaped unqualified praise on the Cheyenne methods of dispute resolution. They used terms such as "juristic beauty" and "legal genius" in referring to how the Cheyenne reconciled law's need for certainty with the dictates of individual justice. ${ }^{20}$ On one level, The Cheyenne Way's description of tribal culture contrasted starkly with the more condescending opinions of the time. But, on a deeper level, this admiration seemed to mask the book's evolutionary view of Cheyenne culture. While on the surface Llewellyn and Hoebel celebrated Cheyenne legal culture, underneath the authors seemed to imply that "primitive" societies, like the Cheyenne, remained well behind in the sociocultural evolutionary process. Seen in this light, The Cheyenne Way appears hopelessly paradoxical.

To understand the self-contradictory aspects of The Cheyenne Way, one must first understand the historical roots of the Cheyenne research project. Llewellyn's fascination with preliterate societies and the methods of anthropology preceded his collaboration with Hoebel. Though he had boasted of carefully studying nearly every diverse group he had come in contact with, Llewellyn's ethnographic skills probably did not take any rigorous, scholarly shape until he had established himself at Columbia. By the early 1930s, Llewellyn had been appointed the Betts professor of jurisprudence, and had made a name for himself among the scholarly circles of New York. Through his contact with Boas and Benedict, and his reading of anthropological works on law, Llewellyn's interest in tribal cultures became heightened. Boas had introduced Llewellyn to Hoebel, and the initial meeting led eventually to Llewellyn's supervision of Hoebel's doctoral study of the Comanche, which Hoebel completed in 1934 (Vincent 1990, 244).21 The

20. Such high admiration sparked some skepticism among the book's critics, including the anthropologist Robert Lowie, who questioned whether the Cheyenne truly exhibited any unique or exceptional way of smoothing tensions (Lowie 1942).

21. Llewellyn also served on a number of other anthropology department dissertation committees, including Jane Richardson's doctoral study of the Kiowa (Vincent 1990, 244). Llewellyn also instructed Sally Falk Moore while she was at Columbia Law School (Moore 
Comanche, and for that matter the Cheyenne, became a small part of what Llewellyn was envisioning as a much broader study of "primitive law."

Before Llewellyn could embark upon this larger, comparative analysis of "primitive law," he had to convince his anthropology colleagues of the merits of such a study. Most academic anthropologists in the 1930 s were skeptical of finding any law among the Indians. Ruth Benedict professed "both ignorance and disinterest," and Boas himself expected American Indian culture to be "devoid of legal aspects" (Vincent 1990, 244). Ralph Linton, an anthropologist who had conducted fieldwork among the Comanche, was equally incredulous (Twining 1973, 154). Llewellyn was not, however, out to prove the existence of law in preliterate societies. That had already been done many years earlier by Malinowski's functional analysis of reciprocal obligations. What Llewellyn had in mind was to subject Western ideas about law to a large-scale comparative study. Dissatisfied with Malinowski's functional explanations, Llewellyn was probably drawn to Boas's more historical interpretation of culture. Thus, the young law professor, embarking upon a large-scale research project, eagerly sought the approval of Boas, the then-dominant figure of American anthropology. Hoebel's work with the Comanche likely convinced Llewellyn that more work should be done with Native Americans. Llewellyn also consulted Joseph P. Chamberlain-a colleague on the law school faculty who specialized in international law-about the benefits of comparative analysis. With Hoebel's and Chamberlain's assistance, Llewellyn persuaded Boas of the possibility of fruitful analysis of American Indian political and legal institutions. Together with Boas and Chamberlain, Llewellyn began "The Project on American Indian Law."22

Funded by Columbia University's Council for Research in the Social Sciences and the American Council of Learned Societies, "Project \#81: Research in American Indian Law" sought to find "the relation between legal institutions and other phases of a culture" (Chamberlain, Llewellyn, and Boas 1935; Boas and Llewellyn 1935). Guided mainly by Boas and Llewellyn (Llewellyn 1935c), the project, first, gathered Hoebel's work with the Comanche and other ethnographic studies of American Indians to show that grounds existed for a large-scale study of tribal law. Bernard Aginsky's work with the Pomo in California, Julius Lipsky's study of the Northern Algonquin, and Alexander Lesser's work with the Kiowa were to be combined with Hoebel's analysis of the Comanche and Shoshone to demonstrate the merits of a comparative approach to tribal law (Llewellyn 1935c). The Cheyenne were added to this mix because they had been in historical

1999). And Moore also had contact with Columbia's anthropology department as an undergraduate at Barnard College.

22. Though it is uncertain when the project precisely began, it is likely that it was sometime in 1934 after Llewellyn and Hoebel had been discussing the Comanche (see Llewellyn 1934). 
contact with the Comanche (Boas and Llewellyn 1935), and because even the most skeptical anthropologists thought the Cheyenne had some organized bodies that wielded coercive powers (Twining 1973, 155).

The aim of the project was nothing short of a full-fledged understanding of the legal institutions of the American Indians. The working hypothesis to be tested was whether effective legal institutions paralleled "the growth of executive authority" and "economic organization" among Indian cultures. The notion of studying how societies developed over time was a theme that had captured Llewellyn's imagination. American Indian cultures promised to be informative objects of such a study because of their similarities and contrasts. "There are enough gradations of cultural development among peoples of similar cultures living in similar conditions," the project's proposal stated, "to make meaningful comparisons possible, and perhaps to enable lines of institutional development to be explored." The proposal continued: "There is enough range of contrast available both as to degree of development and as to economic and political culture types, to offer real hope of reaching a buttressed judgment as to the relation of various types of legal institutions to other phases of a culture" (Boas and Llewellyn 1935, $1-2)$.

Although the language of the project's proposal was somewhat general, phrases such as "gradations of cultural development" and "degree of development" seem to suggest that, despite Boas's participation, Llewellyn had in mind a hierarchy of sociocultural systems. Because of the "range of contrasts available," Llewellyn anticipated that a comparative study of Native American legal institutions could illuminate the stages of evolutionary development from primitive to modern societies. While Llewellyn did not explicitly entangle his evolutionary view with the biological determinism and racialist assumptions that accompanied classical nineteenth-century evolutionism, Llewellyn's tone implied an ethnocentric bias that contradicted, and hence marred, his analysis of so-called Cheyenne legal genius. Other social scientists at the time used similar evolutionary language, but Llewellyn's prejudice appears particularly troubling because it was shrouded by the textual guise of celebrating Cheyenne legal culture. Llewellyn's bias was hidden behind his desire to demonstrate the connections between law and culture. Project \#81 was designed as a series of intensive, empirical case studies that would show how tribal law was, in fact, inextricably tied to Indian culture. But once the initial fieldwork with the Cheyenne began, Llewellyn's aspirations expanded, and in his request for additional funding, Llewellyn intimated that comparative analysis of tribal law could not be limited to American Indians; it had to be stretched to the corners of the globe to include monographs on Philippine and African tribes as well (Llewellyn 1935d). 
Despite such immense ambitions, a large-scale comparative analysis of tribal law never materialized. ${ }^{23}$ Financial constraints imposed by the Great Depression, and Llewellyn's other responsibilities, limited the results of Project $\# 81$. Because the project led to the publication of only a limited number of studies, ${ }^{24}$ The Cheyenne Way became the bedrock of Project $\# 81$. Placing the book in the context of this larger study highlights the inconsistency in Llewellyn's and Hoebel's theories. The Cheyenne Way itself is a tribute to Cheyenne adjudication, a Rousseauist romanticization of Native American social practices. But Project \#81 suggests that the Cheyenne project was meant to be a case study in a much larger analysis of how "primitive" communities develop, or evolve, into more modern and complex societies.

Before one can conclude that Project \#81 is evidence of Llewellyn's neo-evolutionary view of cultural development, one must recall that Boasthe scholar critical of one-dimensional evolutionary theories-was also a supporter of this research project. No one had done as much as Boas had to confront late-nineteenth-century views of cultural evolution. Boas spent the better part of his life combating the belief in grand, universal laws of unilinear development. By questioning the inheritance of acquired characteristics and focusing on the environmental aspects of human development, Boas assisted in dismantling the prevailing, unilinear model of evolution (Stocking 1982, 287; Ross 1991, 319). His brand of cultural relativism supported the argument for biological racial equality and for an historical conception of culture (Stocking 1974; Degler 1991). ${ }^{25}$ Thus, as a modern pluralist, Boas would have no interest in supporting a research project that aimed to revive evolutionary thought in a different guise.

Yet if Llewellyn did not explicitly endorse an evolutionary view of legal development, his teachings or at least what his greatest disciple in the field of legal anthropology took from his teachings seem to suggest otherwise. As Llewellyn's junior collaborator in The Cheyenne Way and his longtime friend, Hoebel carried Llewellyn's juristic method and his neo-evolutionary tone to the next generation of scholars. Hoebel hailed "primitive law" as the "henchman of legal realism" (Hoebel 1954), and he continued to describe the "juristic beauty" and genius of Cheyenne dispute resolution (Twining 1973). Hoebel also continued to echo the importance of comparative analysis, something he had learned while working with Llewellyn. "By seeing

23. In the mid-1950s, Hoebel, with Llewellyn's assistance, spearheaded the attempt to create a committee on comparative legal dynamics, which had as its aim and method goals very similar to the Indian law project (see Herring 1955).

24. Hoebel's study of the Comanche was one of the published pieces that had connections to Project \#81 (see Hoebel 1940).

25. "The main object of ethnological collections," Boas once wrote, "should be the dissemination of the fact that civilization is not something absolute, but that it is relative, and that our ideas and conceptions are true only so far as our civilization goes" (Stocking 1974, 66). 
how societies other than those belonging to our own historical culture and tradition conceive their problems of government and legal control," wrote Hoebel in the syllabus of one of his classes, "the student becomes more able objectively to analyze and judge the political institutions which he must concern himself with in his present society" (Hoebel 1954?). Anthropology thus provided one with a fresh perspective, or what Llewellyn called "new eyes" (Llewellyn 1960, 513).

This fresh perspective allegedly provided by comparative analysis was rarely free of any ethnocentric bias. The comparative perspective had for Hoebel, and may even have today, ${ }^{26}$ an implicit comment about stages of development and the hierarchy of simple and complex cultural institutions. While on the one hand Hoebel learned to commend the juristic beauty of the Cheyenne, he also learned, from Llewellyn, to look for "degrees of cultural gradation" as symbolized by the "degrees of development" in legal institutions and "economic and political culture types." The neo-evolutionary thread, it appears, was part of the fabric of comparative analysis. No where was this legacy of Llewellyn's teachings more apparent than in Hoebel's own textbook on legal anthropology. In The Law of Primitive Man (1954), Hoebel used "jural postulates" derived from five societies to demonstrate the "trend of law." As he saw it, the general direction of evolution could be seen in the shift from private to public methods of dispute resolution, from selfhelp to government control. As societies become more complex, "rights and responsibilities for the maintenance of the legal norms are transferred from the individual and his kinship group to the agents of the body politic as a social unity." Hoebel took this evolutionary view to global levels, arguing that this transfer process could one day foster the creation of a world community (Hoebel 1954, 142-43, 329).

By postulating the evolutionary explanation, Hoebel perpetuated the binary distinction between primitive and modern societies that was implicit in The Cheyenne Way. Both Llewellyn and Hoebel were intellectually indebted to "Papa Franz" and the Boas-school of cultural anthropology. ${ }^{27}$ Their implicit neo-evolutionary theories thus disdained any fixed, unilinear evolution of law. The Cheyenne were a prime example for the two scholars of a culture that had traversed the whole range of evolutionary stages, a culture that remained relatively homogenous but was able to develop sophisticated methods of dispute resolution. Yet while allowing for greater

26. As Laura Nader has recently noted, the comparative perspective remains an essential part of the anthropological approach: "In anthropology the starting perspective is comparative; that is, even if practices are particularistic, the field itself still describes itself as comparative whether comparative methods are used or not. That is, unlike legal scholars, anthropologists start with a comparative perspective, a comparative consciousness, whether explicit or not" (Nader 1998, 753).

27. In his correspondences with Hoebel, Llewellyn often referred to Boas as "Papa Franz" (Llewellyn 1948). 
diversity within the ladder of evolution, Llewellyn and Hoebel remained tied to a teleological view of progress from simple to complex societies. The use of phrases such as "trend of law," "gradations of cultural development," and "degrees of development" perpetuated the evolutionary notion of a qualitative hierarchy of societies, but with a twist. In Llewellyn's and Hoebel's estimation, the movement from simple to complex societies was not a fixed trajectory, as the nineteenth-century evolutionists argued (Stein 1980; Stocking 1982). Rather, Llewellyn and Hoebel believed that societies could evolve at varying stages in the development toward modernity. The Cheyenne demonstrated to them that this movement could occur in a more fluid fashion, rather than by required steps of discrete development over time.

In describing the intellectual influences of The Cheyenne Way, Llewellyn identified Hoebel as a Boas-schooled anthropologist and the book as the result of the "inescapable combination of Boas-Sumner-Weber ideas" (Llewellyn 1940?). What one is to make of this odd combination of thinkers is uncertain, except to say that it gives credence to Hull's characterization of Llewellyn as a "bricoleur" (Hull 1997, 5). Harnessing the cultural relativism of Boas with Sumner's conservatism and Weber's ambivalent legal rationality is indeed quite an amalgamation of social theories. ${ }^{28}$ What does seem clear, however, is that The Cheyenne Way and the larger research project, as well Hoebel's subsequent scholarship, were all reifying a binary distinction between primitive and modern societies - a distinction that remains a part of interdisciplinary work today (Ferguson 1997; Abu-Lughod 1993). ${ }^{29}$ In this way, it appears that Llewellyn and Hoebel embraced Sumner and Weber much more than Boas. Yet, the contribution of the trouble-case method and the reproduction of a neo-evolutionary theory are not the only legacies of The Cheyenne Way. The text is also significant for what it has added to, and what it has missed, about the plurality of legal cultures.

28. Llewellyn may have been attracted to Sumner and Boas because of their varying uses of cultural relativism. Sumner, as a social Darwinist, subscribed to a politically conservative form of cultural relativism that privileged the mores and folkways of particular groups as determinative and appropriate. Boas, on the other hand, gave cultural relativism a radical edge, as he questioned the appropriateness of any one set of cultural norms.

29. Ferguson has suggested that at least in the context of development theory, even contemporary anthropology has been unable to escape this binary distinction between primitive and modern societies, or what Ferguson calls "anthropology's evil twin." Similarly, AbuLughod has argued that anthropologists in their attempts to explain cultural difference have invariably reified culture as a bounded totality separate from the particular events and people that make up particular social practices. 


\section{THE (LIMITED) LEGAL PLURALISM OF THE CHEYENNE WAY}

Early in his academic career, Llewellyn was attracted to the anthropological study of law because it emphasized that law is embedded within a society's culture. Recall that Llewellyn was pleased that modern anthropology provided the study of law with much-needed cultural context. Llewellyn admired "the care with which the now differentiated legal practices are being set in the oyster of the culture which has secreted them." In that same manuscript, he also bemoaned anthropology's neglect in studying American subcultures. Llewellyn, the "half-lawyer, half-sociologist," was well aware that nearly every society contains a multitude of methods to maintain order and social cohesion. His lifelong sociological observations of subcultures such as "boys-groups in summer camp; ... German-Americans in New York; Jews in New York; . . The National City Bank, 1920-22" were all examples of how subgroups within a larger society created their own norms and processes of socialization (Llewellyn 1935a, 2, 3, emphasis in original). The Cheyenne Way, too, was an attempt to examine how potential subgroups within a seemingly homogenous society interacted during moments of crisis, and how distinct groups such as rival tribes resolved their disputes.

Although it may be a slight exaggeration to suggest that Llewellyn and Hoebel explicitly advanced notions of "legal pluralism" as it is understood today, both the theory and data of The Cheyenne Way demonstrate that the authors were keenly aware that nearly all societies contain a multiplicity of legal norms and processes. For instance, in constructing the theoretical apparatus of the Cheyenne project, Llewellyn deliberately promoted a capacious view of law to insure that the fieldwork would not exclude nonWestern examples of law. Indeed, one of the most remarkable aspects of The Cheyenne Way is how its authors were able to analyze Cheyenne legal culture without any explicit definition of "Cheyenne law." Llewellyn was fully cognizant of how any premeditated definition established by Western minds would necessarily have an exclusionary effect. ${ }^{30}$

During the drafting stage of The Cheyenne Way, Llewellyn was particularly careful not to formulate any restrictive definition of law. When Hoebel attempted to articulate a "universal definition of law," Llewellyn responded with uncharacteristic anxiety: "I find it very difficult to frame any definition which covers the situation in a non-state, non-authority society, and also has adequate application to a modern society," wrote Llewellyn. "My own approach has been to set up a Weberish 'ideal type' with a good many attributes such as rules with verbal form[;] machinery for enforcernent[;] recognized claim, if needed; of exclusivity when applicable[; the force of the

30. Norbert Rouland has observed how "the ethnocentrism of Western law: the identification of law with the state," has dominated legal anthropology (Rouland 1994, 3). 
state behind action; a specialized enforcing and litigation and counseling personnel-and the like." Adhering to the Weberian terminology, Llewellyn admitted that this "ideal type" will "never find a complete counterpart in life, unless an arbitrary choice is made between the elements of certainty and of justice-a point over which I am still puzzling" (Llewellyn 1938).

To keep the concept of law boundless, Llewellyn was willing to appropriate Weber's methods as he pleased. For Weber, "ideal types" were meant to be heuristic devices that helped disentangle the complexities of modern reality. Llewellyn constructed his "ideal types" as heuristic devices that existed on a linear plane between the simple and complex. "[S]etting up some such [ideal] type at one pole and unpredictable chaos at the other, we can, it seems to me," wrote Llewellyn, "identify certain subject-matters or jobs which law stuff, in various degrees of primitivity or development of form or kind ... is doing or accomplishing in any group or society." Whereas Weber used "ideal types" to contain a multiplicity of ideas, Llewellyn used his "ideal type" as a polar extreme on his spectrum of "the law-jobs that needed to be done" (Llewellyn 1938).

With his appropriation of Weber's “ideal types," Llewellyn subscribed to an extremely particularistic view of law, one that continued to emphasize social processes. Not only was Llewellyn loathe to use a general Western definition of law, he also recognized the multiplicity of local and dynamic processes of law between the poles of chaos and the ideal. "The only absolutely universal characteristics which I find," Llewellyn continued in his response to Hoebel, "consist in the presence of these jobs which need doing, and in a tendency of any steps in the doing of them to take on, if, unless thwarted by intervening causes, some aspects of regularity in regard to both pattern and personnel" (Llewellyn 1938). Thus, for Llewellyn, the processes or procedures of law-jobs were the only universals; all else was left to the diverse particulars of a culture's space and time.

Determining where a legal culture fell on Llewellyn's law-job spectrum could be accomplished by looking at how the culture as a whole handled its moments of conflict. The "trouble-case" methodology was again proclaimed by its principal author as the method that could discern the multivalent, nonarticulated norms of a culture while highlighting how the culture resolved tension and maintained social cohesion. Since Llewellyn and Hoebel were using Cheyenne cases to show that the meaning of law was to be found in wider cultural processes, cases of conflict were not seen as isolated instances separate from society; they were the "crucibles" in which "all other vital aspects of culture" shined through.

Llewellyn's gestures toward legal pluralism were not limited to the theoretical ruminations of The Cheyenne Way. The study's empirical evidence informed his theory, and thus Hoebel's fieldwork supported the notion that Cheyenne "law-ways" exhibited multiple and often conflicting legal norms 
and processes. Consider, for example, the contrast between disputes among family members and those among tribes. When domestic disputes arose, Llewellyn and Hoebel noted that the "legal position of Cheyenne women, combined with their strong spirit, gave them an usual power over their warrior husbands." In the cases of abusive spouses and negligent husbands, the wife's family arbitrated disputes, regulated compromises, and doled out punishments. The conflict was kept within the social field of the family; it was not settled by the more centralized and political Cheyenne Military Societies or the Council of Forty-Four (pp. 182, 183-87).

By contrast, disputes between tribes entailed a higher level of organization and an appeal to a different level of legal decision making. Llewellyn and Hoebel recounted, in one particular case, how the Cheyenne had made peace with competing tribes. When a group of Kiowa and Comanche approached a traveling band of Cheyenne soldiers with an offer of peace, the soldier chiefs deferred the decision to the tribal leaders who made up the Council of Forty-Four. In the Cheyenne division of labor, it was not up to the soldiers to make decisions regarding external relations. Such decisions were left to the elder statesman of the council. In this case, however, the council requested a recommendation from the soldiers, while reserving the final authority on any decision. The Cheyenne ultimately made peace with the Kiowa and Comanche in this instance, but what Llewellyn and Hoebel found most significant about this process was the mutual deference and cooperation among the two subgroups-the soldiers and the tribal chiefs. "So smooth a delegation of an important decision, inverting the pyramid without any bickering, yet with the machinery at all points for the sensing of opinion," Llewellyn and Hoebel wrote, "is an act of beauty" (pp. 91-93). Unlike a domestic grievance, diplomatic relations involved larger group interaction and links to third parties, both of which dictated that another type of governing process, besides the one used by families, would be more appropriate. Llewellyn and Hoebel, moreover, suggested that the settlement of domestic disputes differed from the settlement of tribal ones in hierarchy, not in quality. Cheyenne society contained a body of stratified subgroups, each of which had its own "law-ways." Despite being a relatively homogenous culture, the Cheyenne, Llewellyn and Hoebel argued, had what the anthropologist Leopold Pospisil later called different "levels of law" (Pospisil 1971). In this way, Llewellyn and Hoebel were pioneers in describing the legal pluralism implicit in the seeming solidarity of communities (Cotterrell 1995).

By describing the multiple levels of Cheyenne dispute resolution, Llewellyn and Hoebel also illuminated the malleable and dynamic nature of Cheyenne legal customs. Writing at a time when most legal scholars depicted "other" non-Western cultures as bounded, static environments, Llewellyn and Hoebel-again by focusing on dispute resolution processes- 
defined Cheyenne culture as a flexible set of social practices that were constantly being recreated in the "crucible of conflict." Just as many anthropologists were turning their attention in the 1930s and "40s toward the processes of assimilation and acculturation (Vincent 1990, 152-222), Llewellyn and Hoebel were also interested in how Cheyenne culture changed over time. For Llewellyn and Hoebel, law was not merely a reflection of a static, social consensus, but rather a site of cultural contestation, a place where hegemony and resistance constantly came into conflict. Nowhere was this more apparent then in those instances in Cheyenne culture when individual will resisted group control, or when new types of friction required new social practices. How the Cheyenne handled these moments of crisis, how they used their flexible notions of law to keep pace with their dynamic culture, was what Llewellyn and Hoebel identified as the "juristic beauty" of the Cheyenne.

The conflict between individual desires and community norms revealed most clearly how the Cheyenne adapted their legal decisions to allow for the coexistence of individual expression and social harmony-that is, how they allowed for resistance without anarchy. When "Sticks Everything Under His Belt" was ostracized by the tribe for hunting alone in violation of the tribe's rule of communal hunting, one tribal chief stepped forward, several years later, to convince the other chiefs that the violator had learned his lesson. This chief was required, however, to endure the sacrifice of giving a Sun Dance to the tribe. "Sticks Everything Under His Belt's" actions were a first for the tribe; never before had a person so boldly placed individualism ahead of the tribal community. How the tribe dealt with such dissension, and how it eventually allowed for rehabilitation were, for Llewellyn and Hoebel, a thing of beauty. The Council of Forty-Four resolved the matter using "the dissident's own declaration of a new legal concept, and of himself as flatly within it: He says he is Out-of-Tribe; so be it-Out-ofTribe he is." But the chiefs also allowed for the possibility of recantation and readmission. Llewellyn and Hoebel were astonished by how the Cheyenne dealt with this precedent-setting conflict. In the authors' eyes the solution of banishment and possible return was consistent with both tribal standards and progressive reform. "[H] ow a solution could more closely fit into the going institutional structure, and at the same time carry that structure forward, we cannot see," wrote Llewellyn and Hoebel. "Nor can we imagine more effectively individuated reform treatment, or more unforgettably dramatized record for the young" (pp. 124-25).

The case of property claims among the Cheyenne provided an equally illuminating example of how flexible notions of law kept abreast of an unbounded and changing culture. When a friend of "Wolf Lies Down" borrowed a horse and did not return it for over a year, "Wolf Lies Down" pleaded his concern with the council, which approached the borrower. 
Although the borrower had left his bow and arrow as "security" with "Wolf Lies Down," the old custom of free utilization of another's goods was creating friction. The borrower was persuaded to resolve the issue by giving "Wolf Lies Down" a new horse in lieu of the one that he had borrowed. Afterwards, the council of chiefs realized that, with an increased fluidity of property relations, some form of legislation needed to be enacted; they declared that henceforth one could not borrow an owner's horse without the expressed permission of the owner. Llewellyn and Hoebel were impressed by how the tribe had dealt with this problem. First, the council set out to resolve the individual dispute between "Wolf Lies Down" and the borrower, and then, only secondarily, did they move into new social policy. Thus, both the individual claims and the tribe's concern about future borrowings were dealt with effectively. It was precisely this unique ability to deal with both law's demand for certainty and its need to adapt to changing circumstances that Llewellyn and Hoebel admired in Cheyenne culture (p. 129).

Modern American law, Llewellyn and Hoebel believed, had much to learn from the Cheyenne. Llewellyn had been exasperated by modern American law's inability to adapt to a complex, changing world. Legal formalism, and an adherence to conceptual notions of certainty, Llewellyn believed, had ossified the law's ability to meet the demands of the society it was meant to serve. "'Law' is, in function, a means to reach much the same ends which the feeling of 'justice' also reaches for," wrote Llewellyn and Hoebel. "When the two grow distinct, the tool 'law' has ceased to be cleanshaped to its reason" (p. 333). The study of the Cheyenne reaffirmed the possibility that law and justice could indeed be reconciled.

[W] hat the Cheyenne law-way shows . . . is that a significantly high development of certainty and clarity, of prospective outcome, felt even by most litigants in the heat of controversy, can be achieved on a not unelaborate scale, without the growth of such 'law' and 'legal procedure' as rigidifies upon itself, and comes so into opposition with the felt justice of a newer generation. The Cheyenne law-way shows more. It shows that developed ritual, together with some quantum of very clear rule and imperative procedure, can be handled in favorable circumstances with flexibility, in terms of need, yet with no sacrifice at all of feeling for certainty and form. (P. 333)

In addition to demonstrating that flexible "law-ways" could keep pace with a dynamic society, The Cheyenne Way also underscored how such flexibility emanated from a pervasive view of "law-jobs." The authors believed the Cheyenne had mastered the ability to infuse legal and social norms into the everyday social practices of society. As Laura Nader has noted, this view of Cheyenne "legal process made the argument that even in our own culture we should include under law much more than what is centered in judges 
and in the courts" (Nader 1992, 19). Indeed, Llewellyn and Hoebel made that precise claim in emphasizing what the implications of The Cheyenne Way were for modern American society. "What the Cheyenne law-way does for Americans here," wrote Llewellyn and Hoebel, "is to make clear that in ideal conditions the art and job of combining long-range justice, existing law, and the justice of the individual case, in ways reasonably free of the deflecting pressures of politics and personal desire, need not be confined to the judging office. It can be learned elsewhere and learned rather generally" (p. 335, emphasis in original). This appeal to extrajudicial authorities for social harmony was at the heart of The Cheyenne Way's comparative analysis. Students of The Cheyenne Way were to take away from their reading not the notion that modern American society should look to the Cheyenne to borrow ideas about legal process or conflict resolution. Clearly, the particular ways of the nineteenth-century Cheyenne could not be applied directly to modern, twentieth-century America. But viewing and understanding another legal culture-seeing how they resolved their disputes effectively and harmoniously-could allow not only Llewellyn's America but even contemporary America to see their particular legal system in a new light.

Llewellyn's analysis of Native American legal culture did not end with The Cheyenne Way. During the mid-1940s, Llewellyn collaborated again with Hoebel in another Columbia University-sponsored study of Native American law and governance. This time the study focused on the eastern Keresan-speaking Pueblo of New Mexico. Although Llewellyn participated actively in the fieldwork, which stretched over several summers from 1945-49, the project was never completed. Distracted by a full teaching load during the academic years, and the responsibility of directing the Uniform Commercial Code, Llewellyn could not commit the same resources to studying the Pueblo as he had for the Cheyenne. But the Pueblo study had other drawbacks. Unlike the Cheyenne study, the Pueblo project lacked a clear objective from the beginning. It had no large-scale comparative project, similar to Indian Project $\# 81$, that could provide context; nor did it have a defined methodology of focusing on disputes or other social processes to anchor it. Outside of a modest proposal for drawing comparisons between the centralized structures of the Pueblo with the Soviet Union (Twining 1974, 361-63), the Pueblo study yielded only limited scholarly results. ${ }^{31}$

Instead, Llewellyn spent his time with the Pueblos helping them record the fundamental aspects of their legal institutions and procedures. As an unofficial consultant, Llewelly engaged tribal leaders in drafting a set of Pueblo codes. With this project, he put into practice his ideas about legal pluralism. In Llewellyn's mind, the Pueblo existed, like the Cheyenne, as an insulated and self-contained community that had somehow resisted the

31. Hoebel eventually published some of the findings from the Pueblo fieldwork (Hoebel [1969]1997). 
forces of Western law and imperialism. He saw Pueblo law as a separate form of authority, operating on a level far removed from the Western world in which it participated. By helping draft a set of codes, Llewellyn believed he could construct a type of quasi-international accord that would harmonize Pueblo rules with American principles of individual rights and due process. The Pueblo, like the Cheyenne, were treated as a case study illustrating the benefits of comparative legal analysis.

Though Llewellyn spent a great deal of time with the Pueblos, it was the Cheyenne that left a lasting impression on his legal theory. Toward the end of his life, Llewellyn acknowledged how critical his ethnographic study of Cheyenne culture was in the broadening of his own legal thought. In The Common Law Tradition, Llewellyn credited the Cheyenne for giving him the hope and justification to imagine a more effective vision of American law. "[T]he law of the Cheyenne Indians made clear to me," wrote Llewellyn, "what I had never before dreamed: to wit, that law and justice had no need at all to be in conflict or even in too much tension, but could instead represent a daily working harmony." Prior to The Cheyenne Way, Llewellyn had viewed the rigidity of law with a complacent attitude and jaded eyes. "[I]n common with most lawyers, and indeed with most jurisprudes," wrote Llewellyn, "I had mostly taken for granted a sort of perpetual struggle between the needs of regularity and form and of the precedent-phase of justice on the one side and, on the other, any dynamic readjustment of a going system to what just needed to be done" (Llewellyn 1960, 513). The Cheyenne showed Llewellyn that this struggle need not be perpetual.

Although Llewellyn's early antiformalism, especially his pivotal role in the legal realist movement, probably made him less complacent then he let on, his work with the Cheyenne contributed to his increased optimism about the possibilities of legal change. He admitted that the Cheyenne and the "trouble-case" method showed him that particular instances of conflict did not have to retard the changing process of law. "I had to get to the Cheyenne in order to wake up to the fact that tension between form, or precedent, or other tradition and perceived need requires, in nature, to be a tension only for the single crisis," wrote Llewellyn. "It does not have to be a continuing tension in the legal system as a whole, because an adequately resilient legal system can on occasion, or even almost regularly, absorb the particular trouble and resolve it each time into a new, usefully guiding, forward-looking felt standard-for-action or even rule-of-law." The Cheyenne had, in short, altered Llewellyn's complacent and jaded outlook, allowing him to see the possibilities of other forms of dispute resolution and legal reform. "To think of such steady readjustment," wrote Llewellyn, "was to get a new pair of eyes" (Llewellyn 1960, 513).

Yet even with these "new eyes," Llewellyn and Hoebel overlooked how their conception of Cheyenne culture was grossly limited. Their legal 
pluralist focus on peoples and processes allowed them to see the internal dynamics of Cheyenne culture-how subgroups had their own "levels of law" and how individuals resisted dominant cultural practices. ${ }^{32}$ But their research and writing did not recognize the external pressures on Cheyenne culture. Llewellyn and Hoebel failed to realize that culture is not only recreated from within, but that it is also constantly altered from without: The dynamic nature of culture is not only a function of the interactions among subgroups, it is also a result of a society's connections to larger global forces.

Llewellyn and Hoebel treated the Cheyenne-and later the Pueblosas an untouched social group living on the frontiers of American society, when in fact they were one of the early Native American groups to occupy "contact zones" with American state power (Pratt 1992). The Cheyenne were best remembered at the time for their place in American popular culture as the Indian tribe that, together with the Sioux, had defeated Custer. Yet Cheyenne contact with American domestic imperialism existed well before the battle of Little Big Horn. As early as 1825 the Cheyenne had signed a treaty with the U.S. government sequestering Native American lands, and by the 1870 s white settlements and forts had encircled nearly all Cheyenne territories (Powell [1969]1998, 83; Stands in Timber and Liberty 1998,160 ).

The Cheyenne were also at the mercy of the imperatives of American trade. Though the Cheyenne had been trading with European colonizers since at least the eighteenth century (Moore 1987, 186), the expansion of American economic interests into the Great Plains in the nineteenth century brought with it a decimation of buffalo herds and an active whiskey trade (Powell [1969]1998, 84). Even Hoebel's fieldwork for The Cheyenne Way was affected by American cultural and economic expansion. In the summer of 1936, the second summer of fieldwork, Montana was plagued by a devastating drought that stretched across the Plains. The research with the Cheyenne had been slow going, and Hoebel grew increasingly skeptical of the project. But the material conditions of the Cheyenne "research subjects" were rescued, Hull tells us, by the arrival of a Hollywood film crew that hired 250 Cheyenne as extras, paying them five dollars a day (Hull 1997, 289).

Even this explicit intermingling of cultures went unnoticed in the text of The Cheyenne Way. Llewellyn and Hoebel seemed oblivious to the notion that the introduction of wage labor, even for a temporary period, could alter Cheyenne understandings of legal meanings and cultural relationships. Llewellyn and Hoebel were using oral histories to recreate an understanding of Cheyenne legal processes, but the authors failed to investigate whether

32. By focusing on peoples and processes The Cheyenne Way gestures toward a theory of agency, but as Sally Falk Moore has noted, this aspect of the text remained undeveloped by the authors (Moore 1999). 
their informants, or the narratives that they described, were affected by the external pressures placed on Cheyenne culture. Thus, while Llewellyn and Hoebel recognized that law could play a significant cultural role within Cheyenne society in redefining meanings and relationships-a role that the rigidity of American legal formalism inhibited-they nonetheless ignored the fact that this redefinition occurs in the context of state power and economic coercion.

Contemporary scholarship on legal pluralism has moved beyond the confines of The Cheyenne Way. Unlike the modern/primitive divide that has persisted in legal anthropology, the forces of Western colonialism have not been ignored in current studies of legal pluralism. Anthropologists and legal scholars have comprehended that forces outside a given community can do much more than merely assimilate minority societies into the dominant culture. Today's scholars better perceive "the mutually constitutive nature of law and the social relations of colonialism" (Merry 2000). They have been exploring new and creative ways to view the legal struggles of marginalized groups (Starr and Collier 1989; Lazarus-Black and Hirsch 1994). Llewellyn and Hoebel, however, were unable or unwilling to garner such a perspective. ${ }^{33}$

The Cheyenne of the nineteenth and early twentieth centuries were immersed within a web of American capitalist expansion, a web that over time produced the Cheyenne culture that Llewellyn and Hoebel had been observing. The Cheyenne Way closes with a memorable gesture toward the plight of the Cheyenne: "All [is] in full flux - while the buffalo vanish, and the white man moves inexorably in. Cheyenne law leaped to glory as it set" ( $\mathrm{p}$. 340 , emphasis in original). With these parting words, Llewellyn and Hoebel fired their final salvo against the notion that culture is a fixed and homogenous set of beliefs and attitudes. The two authors recognized throughout their research and writing that Cheyenne culture, like all cultures, is constantly "in full flux." What the scholars failed to comprehend was that this flux was not limited to internal interactions. Cheyenne culture was recreated and reproduced precisely because the buffalo vanished and the white man moved inexorably in.

\section{CONCLUSION}

The legal academic and the cultural anthropologist who ventured to Lame Deer, Montana, in 1935 to study the legal culture of the Cheyenne were not the same persons who left. The experience with the Cheyenne had

33. Because the authors were unable to place the Cheyenne within this greater sociopolitical context, they were also unable to see how the Cheyenne may have appropriated American notions of law to resist certain aspects of American expansionism. For more on cultural appropriation within a context of legal pluralism, see Merry 1999 and 2000. 
changed both men. The lawyer, who was a prominent member of the group of young, irreverent legal scholars known as legal realists, many years later credited his experience with the Cheyenne as an exhilarating encounter. The young anthropologist, as the devoted disciple of his elder collaborator, carried the message of Cheyenne "legal genius" and legal development to the next generation of scholars. The Cheyenne, for their part, as subjects of the ethnographic study, demonstrated that people and processes constitute the shifting cultural matrix, and that flexible and malleable sets of "lawways" can keep pace with this changing cultural context.

As one of the early collaborative efforts between law and the social sciences, The Cheyenne Way is an integral part of the law and society heritage. The cooperation between the Cheyenne, the lawyer, and the anthropologist has become an important part of the genealogy that makes up the current strand of interdisciplinary work. In both its methodology of studying dispute resolution and its romanticization of native processes, The Cheyenne Way has left a legacy of innovations and limitations. Its focus on the "crucibles of conflict" has shown how social processes are inextricably linked to substantive rules. The text's place within the larger context of Indian Law Project $\# 81$ suggests, however, that while the authors were willing to dissolve the distinction between substance and process, their nostalgic view of Cheyenne "law-ways" only reified as evident and natural the neo-evolutionary binary between primitive and modern societies.

Similarly, as an original work in the field of legal pluralism, The Cheyenne Way is both informative and somewhat restrictive. The book demonstrates with some ethnographic clarity that Llewellyn and Hoebel did not presume Cheyenne culture to be a discrete and bounded entity. Their focus on dispute resolutions as a supplement to the ideological and descriptive approaches allowed them to recognize how subgroups and individuals within Cheyenne culture used differing sets of legal procedures and practices to resolve tension and keep Cheyenne law-ways abreast of changing Cheyenne culture. But the authors did not extend this view of culture as a site of dynamic activity beyond the bounds and contexts of the society under examination. By marginalizing the influence of more systemic forces and leaving unexplained why the buffalo vanished and the white man inexorably moved in, the authors did not realize the full scope of the native culture they set out to explore. Just as they perpetuated a neo-evolutionary hierarchy of primitive and modern societies, they also reproduced a view of native culture as somehow untouched and isolated from the greater context of continental migrations and capital flows.

The insights and weaknesses of The Cheyenne Way are still with us today. As the burgeoning literature on the significance of social norms suggests, interdisciplinary legal studies continues to expand our view of social practices and legal processes without fully illuminating the ethnographic 
roots of these practices and processes (Tushnet 1998). If sociolegal scholars are to celebrate the multiple and sometimes conflicting methods of interdisciplinary inquiry (Engel 1999), perhaps we should take the 60th anniversary of The Cheyenne Way as an opportunity to reexamine one of the early attempts at such collaboration. Likewise, before law and society scholars discuss the future path of interdisciplinary knowledge "after society" (Simon 1999), perhaps we should understand the path that has led us to the current law and social moments. Perhaps we should take a better look at the historical context and legacy of The Cheyenne Way.

\section{REFERENCES}

Abu-Lughod, Lila. 1993. Writing Women's Worlds: Bedouin Stories. Berkeley and Los Angeles: University of California Press.

Ansaldi, Michael. 1992. The German Llewellyn. Brooklyn Law Review 58:705-77.

Arnold, Thurman. 1937. The Folklore of Capitalism. New Haven, Conn.: Yale University Press.

Bingham, Joseph. 1930. Letter to Karl Llewellyn, 1 December. Llewellyn Papers, University of Chicago Law School, File R.II.9.

Boas, Franz, and Karl Llewellyn. 1935. Memo to the American Council of Learned Societies. Llewellyn Papers, University of Chicago Law School, File I.I.4.

Chamberlain, Joseph P., Karl Llewellyn, and Franz Boas. 1935. Application to the Council for Research in the Social Sciences, 1 March. Llewellyn Papers, University of Chicago Law School, File I.I.4.

- Comaroff, John, and Jean Comaroff. 1992. Ethnography and the Historical Imagination. Chicago: University of Chicago Press.

Comaroff, John, and Simon Roberts. 1981. Rules and Processes: The Cultural Logic of Dispute in an African Context. Chicago: University of Chicago Press.

Conley, John M., and William M. O'Barr. 1998. Just Words: Law, Language, and Power. Chicago: University of Chicago Press.

Connolly, James J., Peggy Pshirrer, and Robert Whitman. 1998. Alcoholism and Angst in the Life and Work of Karl Llewellyn. Ohio Northern University Law Review 24:43-124.

Corbin, Arthur. 1960. Letter to Karl Llewellyn, 1 December. Llewellyn Papers, University of Chicago Law School, File R.III.15.

-1962. A Tribute to Karl Llewellyn. Yale Law Journal 71:805-12.

Cotterrell, Roger. 1995. Law's Community: Legal Theory in Sociological Perspective. New York: Oxford University Press.

Degler, Carl. 1991. In Search of Human Nature: The Decline and Revival of Darwinism in American Social Thought. New York: Oxford University Press.

Drobnig, Ulrich. 1994. Llewellyn and Germany. In Rechtsrealismus, multikulturelle Gesellshaft und Handelsrecht: Karl N. Llewellyn and seine Bedentung heute, ed. Ulrich Drobnig and Manfred Rehbinder. Berlin: Druncker and Humblot.

Duxbury, Neil. 1995. Patterns of American Jurisprudence. Oxford, U.K.: Clarendon Press.

Ellinwood, Raymond M. Jr., and William L Twining. 1970. Karl Llewellyn Papers: A Guide to the Collection. Chicago: University of Chicago Law School.

Engel, David M. 1999. Making Connections: Law and Society Researchers and Their Subjects. Law and Society Review 33:3-15. 
Ferguson, James. 1997. Anthropology and Its Evil Twin: "Development" in the Constitution of a Discipline. In International Development and the Social Sciences: Essays on the History and Politics of Knowledge, ed. Frederick Cooper and Randall M. Packard. Berkeley and Los Angeles: University of California Press, 1997.

Frazer, James G. 1923. Folklore in the Old Testament. New York: Macmillan.

Gilmore, Grant. 1962. In Memoriam: Karl Llewellyn. Yale Law Journal 71:812-15.

Gluckman, Max. 1955. The Judicial Process among the Barotse of Northern Rhodesia. Manchester, U.K.: Manchester University Press.

Grinnell, George B. 1915. The Fighting Cheyenne. Norman: University of Oklahoma Press.

- 1923. The Cheyenne Indians. New Haven, Conn.: Yale University Press.

Gulliver, P. H. [1969]1997. Case Studies of Law in Non-Western Societies. In Nader [1969]1997.

Herring, Pendleton. 1955. Letter to Karl Llewellyn, 1 April. Llewellyn Papers, University of Chicago Law School, File R.VIII.R.

Hoebel, E. Adamson. 1940. The Political Organization and Law-ways of the Comanche Indians. Menasha, Wis.: American Anthropological Association.

1954. Law of Primitive Man. New York: Atheneum.

1954? Hoebel's Primitive Law Syllabus. Llewellyn Papers, University of Chicago Law School, File I.I.6.

- 1964. Karl Llewellyn: Anthropological Jurisprude. Rutgers Law Review 18:735-56.

- [1969]1997. Keresan Pueblo Law. In Nader [1969]1997.

Holmes, Oliver Wendell Jr. 1897. The Path of the Law. Harvard Law Review: 10:457-78.

Horwitz, Morton J. 1992. The Transformation of American Law 1870-1960: The Crisis of Legal Orthodoxy. New York: Oxford University Press.

Hull, N. E. H. 1997. Roscoe Pound and Karl Llewellyn: Searching for an American Jurisprudence. Chicago: University of Chicago Press.

Hunt, Alan. 1978. The Sociological Movement in Law. London: Macmillian.

Kalman, Laura. 1986. Legal Realism at Yale, 1927-1960. Chapel Hill: University of North Carolina Press.

Kamp, Allen R. 1995. Between the Wars Social Thought: Karl Llewellyn, Legal Realism, and the Uniform Commercial Code. Albany Law Review 59:325-97.

1998. Uptown Act: A History of the Uniform Commercial Code: 1940-49. Southern Methodist University Law Review 51:275-348.

Landers, Scott. 1996. Practicing What You Preach Against? Karl Llewellyn, Legal Realism, and the Cheyenne Way. In Law and the Great Plains: Essays on the Legal History of the Heartland, ed. John R. Wunder. London: Greenwood Press.

Lazarus-Black, Mindie, and Susan F. Hirsch, eds. 1994. Contested States: Law, Hegemony, and Resistance. New York: Routledge.

Lessig, Lawrence. 1998. The New Chicago School. Journal of Legal Studies 27:661-91.

Lewis, Sheri H. 1994 The Karl Llewellyn Papers: A Supplementary Guide to the Collection. Chicago: University of Chicago Law School.

Llewellyn, Karl N. [1930]1951. The Bramble Bush. New York: Oceana. 1930. Cases and Materials on the Law of Sales. Chicago: Callaghan.

1934. Letter to Dean Howard L. McBain, Fall. Llewellyn Papers, University of Chicago Law School, File R.XIII.12.

- 1935a. Law in Primitive Culture. Typescript. Llewellyn Papers, University of Chicago Law School, File I.I.6.

. 1935b. Letter to Ad Hoebel, 11 Feb. Llewellyn Papers, University of Chicago Law School, File I.I.3. 
1935c. Letter to Franz Boas, 15 November. Llewellyn Papers, University of Chicago Law School, File I.I.3.

_- 1935d. Memo to Joe Chamberlain, 20 December. Llewellyn Papers, University of Chicago Law School, File I.I.4.

1938. Letter to Ad Hoebel, 36 Jan. Llewellyn Papers, University of Chicago Law School, File I.I.3.

- 1940? Appendix on Allocation of Responsibility [for The Cheyenne Way]. Llewellyn Papers, University of Chicago Law School, File I.I.2.

- 1942. Letter to Edward G. Howard, Esq., Winter. Llewellyn Papers, University of Chicago Law School, File R.IX.

__. 1948. Letter to Ad Hoebel, 23 November. Llewellyn Papers, University of Chicago Law School, File R.VIII.12.

- 1951. Letter to Dean Allison Reppy, 24 May. Llewellyn Papers, University of Chicago Law School, File R.VII.8.

1960. The Common Law Tradition: Deciding Appeals. Boston: Little, Brown.

. 1961. Letter to Professor Denis Cowen, 6 April. Llewellyn Papers, University of Chicago Law School, File R.III.18.

Lowie, Robert. 1942. Book Review. American Anthropologist 44:478-79.

Malinowski, Bronislaw. 1926. Crime and Custom in Savage Society. New York: Harcourt, Brace.

- 1942. A New Instrument for the Interpretation of Law-Especially Primitive, A Review of The Cheyenne Way. Lawyers Guild Review 2:1-12.

Mentschikoff, Soia, and Irwin P. Stozky. 1986. Law-The Last of the Universal Disciplines. University of Cincinnati Law Review 54:695-745.

Merry, Sally Engle. 1999. New Direction: Law, Culture, and Cultural Appropriation. Yale Journal of Law and the Humanities 10:575-603.

. 2000. Colonizing Hawaii: The Cultural Power of Law. Princeton, N.J.: Princeton University Press.

Moore, John H. 1987. The Cheyenne Nation: A Social and Demographic History. Lincoln: University of Nebraska Press.

Moore, Sally Falk. 1999. From Lawyer's Law into the Academic Zoo. Political and Legal Anthropology Review 22:101-105.

Nader, Laura. 1965. The Anthropological Study of Law. American Anthropologist (special pub. The Ethnography of Law) 67(6, pt. 2):3-32.

- ed. [1969]1997. Law in Culture and Society. Berkeley and Los Angeles: University of California Press.

- 1992. Introduction to The Cheyenne Way by Karl N. Llewellyn and E. Adamson Hoebel. New York: Legal Classics Library.

- 1998. Symposium: Comments. American Joumal of Comparative Law 46:751-56.

New York Times. 1962. Karl Llewellyn, Law Expert Dies, 15 February, p. 29.

Papke, David Ray. 1999a. How the Cheyenne Indians Wrote Article 2 of the Uniform Commercial Code. Buffalo Law Review 47:1457-85.

_. 1999b. Karl Nickerson Llewellyn. American National Biography 13:782.

Pospisil, Leopold. 1971. Anthropology of Law: A Comparative Theory. New York: Harper and Row.

Pound, Roscoe. 1943. Sociology of Law and Sociological Jurisprudence. University of Toronto Law Journal 5:1-20.

Powell, Peter J. [1969]1998. Sweet Medicine: The Continuing Role of the Sacred Arrows, the Sun Dance, and the Sacred Buffalo Hat in Northern Cheyenne History. Vol. 1. Norman: University of Oklahoma Press. 
Pratt, Mary Louise. 1992. Imperial Eyes: Travel Writing and Transculturation. New York: Routledge.

Purcell, Edward A. 1973 Crisis of Democratic Theory. Lexington: University of Kentucky Press.

Redfield, Robert. 1942. Book Review: The Cheyenne Way. University of Chicago Law Review 9:366-69.

Riesenfeld, Stefan A. 1994. Reminiscences of Karl Llewellyn. In Rechtsrealismus, multikulturelle Gesellshaft und Handelsrecht: Karl N. Llewellyn and seine Bedentung heute, ed. Ulrich Drobnig and Manfred Rehbinder. Berlin: Druncker and Humblot.

Ross, Dorothy 1991. The Origins of American Social Science. Cambridge: Cambridge University Press.

Rouland, Norbert. 1994. Legal Anthropology, trans. Philippe G. Planel. Palo Alto, Calif.: Stanford U. Press.

Schlegel, John Henry. 1995. American Legal Realism and Empirical Social Science. Chapel Hill: University of North Carolina Press.

Simon, Jonathan. 1999. Law after Society. Law and Social Inquiry 24:143-91.

Stands in Timber, John, and Margot Liberty. 1998. Cheyenne Memories. New Haven, Conn.: Yale University Press.

Starr, June, and Jane F. Collier. 1989 History and Power in the Study of Law: New Directions in Legal Anthropology. Ithaca, N.Y.: Cornell University Press.

Stein, Peter. 1980 Legal Evolution: The Story of an Idea. Cambridge: Cambridge University Press.

Stocking, George W. 1974. A Franz Boas Reader: The Shaping of American Anthropology, 1883-1911. New York: Basic Books.

1982. Race, Culture, and Evolution: Essays in the History of Anthropology, with a New Preface. New York: Free Press, 1968. Reprint, Chicago: University of Chicago Press.

-1999. Interview by author. University of Chicago, October.

2000. "Do Good, Young Man": Sol Tax and the World Mission of Liberal Democratic Anthropology. In Excluded Ancestors, Inventible Traditions, ed. Richard Handler. Vol. 9: History of Anthropology. Madison: University of Wisconsin.

Sunstein, Cass R. 1996. Social Norms and Social Roles. Columbia Law Review 96:903-68.

Tushnet, Mark. 1998. "Everything Is New Again": Early Reflections on the "New Chicago School." Wisconsin Law Review 1998:579-90.

Twining, William. 1973. Karl Llewellyn and the Realist Movement. Norman: University of Oklahoma Press.

1993. The Idea of Juristic Method: A Tribute to Karl Llewellyn. University of Miami Law Review 48:119-57.

Vincent, Joan. 1990. Anthropology and Politics: Visions, Traditions, and Trends. Tucson: University of Arizona Press.

Whitman, James. 1987. Commercial Law and American Volk: A Note on Llewellyn's German Sources for the Uniform Commercial Code. Yale Law Journal 97:156-75. 


$$
* * *
$$

